\title{
Analyzing Errors Committed in Paragraph Writing by Undergraduates
}

\author{
Iman Muwafaq Muslim Muwafaq Al-Ghabra \\ English Department, College of Education for Women, University of Baghdad, Baghdad, Iraq \\ Afrah Suhail Najim \\ Abdullah Al-Ashiq Primary School, Baghdad, Iraq
}

\begin{abstract}
Writing plays a key role in the educational system. Since it is a creative skill, both native and nonnative speakers face difficulties to write in a proper and academic way. The main focus of the present study is to examine the type and frequency of errors in 87 paragraphs written by 87 of the $2^{\text {nd }}$ year students (Department of English, College of Education for Women, University of Baghdad) when practicing paragraph writing as part of their syllabus. To achieve this objective, the researchers have designed a rubric that includes both the recognition and arrangement criteria. According to this rubric, they taught and trained their students how to write a paragraph for 3.5 months. At the end, the researchers gave the participants a title to write a good paragraph. The researchers identified the type and frequency of their errors. Results have been arranged in a descending sequence: grammar, capitalization, spelling, punctuation, formatting, handwriting, and coherence.
\end{abstract}

Index Terms - writing, paragraph writing, error analysis

\section{INTRODUCTION}

Writing is the leading cause of success in an academic achievement; it is becoming increasingly important in linguistics. The dependence on technology has shown some kind of deviation from the academic norms of writing. Therefore, in the new global world, writing in general and writing in English, in particular, has become a central issue of education. Here, Graham and Herbert (2011) state that writing has its positive effect on reading and comprehension, and at the same time, reading has its positive effect on writing. Accordingly, both teaching writing and learning the process of writing should be given their due importance. In this context, the researchers consider writing as one of the fundamental tools in the process of learning to achieve the academic success. Hence, it is logical to focus on the correctness of writing to be error-free and sensible, especially when it is produced by the would-be future teachers. They further believed that to know how to correct writing errors, they must have in mind which criteria to follow in teaching writing. For instance, in the grammar-translation and audio-lingual methods, Homstad and Thorson (1994) referred to the importance of writing as a supporting skill to acquire grammar, and facilitate memorizing language structure. The communicative approach, on the other hand, does not focus on writing. The researchers of the present work asserted Homstad and Thorson (1996) in that they do not give vocabulary and grammar the big role in the process of writing because they think that arrangement, coherence, spelling, and punctuation also have a role in enhancing it.

Another merit of writing is that it reflects creativity. In this respect, since writing is considered a creative skill, it is expected to be error-free in order to attract the readers' attention; however, frequent errors cause distraction. According to AL-Khasawneh's (2014) writing is a mental process which requires three steps: generating ideas, arranging them into sentences, and revising them. According to him, good writing is achieved through adequate knowledge of grammatical rules, lexical items, and logical connections.

The errors committed throughout the process of learning a language should not be always viewed negatively. In this respect, Corder (1967) believes that learning a second language is like learning the mother tongue. In spite of that infants are born with an inherent predisposition, they need to be exposed to their language in order to process their capacity of learning. However, they pass through different stages of committing errors till they reach the stage of perfection. This means that there is no harm associated with committing errors; it is only one of the stages of learning. The difference between acquiring the mother tongue and learning a foreign language is featured by the type of environment that individuals are exposed to. In the case of acquiring the mother tongue, the type of the environment is immersing, happy and encouraging faces make infants feel happy when they start to utter words and phrases; in addition, infants do not feel embarrassed when they commit errors and others correct them. However, the situation is reversed when learning a foreign language; individuals miss the immersion environment; they do not have the same strength of encouragement, and they could not govern the feeling of being embarrassed when they commit errors and be corrected. For this reason, error analysis and using it as a feedback is more effective and accepted by learners in writing than in speaking because learners can revise them thoughtfully away from the embarrassing eyes. 
Other scholars, like Deane et al. (2008) had another point of view. They stated that educators confirm the importance of clear writing to clear thinking. Since writing is a connection between the writer and the audience, the clarity cannot be achieved unless the piece of writing is cultural-linguistic interpretative. This is an authentic reason to make teachers think of their responsibility for paying more attention to guide and direct their students well to improve their writing.

\section{ERROR ANALYSIS AND TYPES OF ERRORS}

Error analysis has grown in importance, specifically in the field of linguistics; accordingly a proliferation of studies using error analysis has been conducted. In this vein, Nzama (2010) attributed the increased interest in using error analysis to the importance of this method in discovering the strategies that learners use when acquiring a particular language. According to the researchers of the present work, error analysis further helps to find new teaching strategies that are based on students' weak points to reduce if not eradicating such errors.

Furthermore, Weireesh (1991; cited Darus \& Subramaniam 2009) highlighted the importance of using error analysis in supporting the learning process. Error analysis has proven to be valuable in pinpointing the difficulties that learners face, and in getting learners' feedback. It is also a tool for deciding which remedial program is suitable to establish. Darus and Sabramaniam (2009) also confirmed in their study that recognizing learners' errors help teachers in preparing the required materials to overcome the learning problems.

On the other hand, Baghzou (2011) stated that teachers of composition feel uncertain about the usefulness of using feedback for their students' writing. This is because they believed that their students repeat the same errors; they adopt Corder's (ibid.) understanding about the similarity between acquiring the native language and learning a foreign language, and about the advantage of using feedback with kids only to correct their native language. This is because Corder (ibid.) believed in the effectiveness of feedback after frequent repetitions. Here, the researchers of the present work highly recommend using error analysis as a feedback for any learners of a foreign language, and not only with kids.

As for the types of errors, generally speaking, the researchers of the current study have categorized errors into two main evaluative types of criteria: Recognition and arrangement. Under "recognition errors", there are the following subcriteria:

\section{a. Grammatical Errors}

Hasyim (2002) referred to the importance of error analysis to both learners and teachers. He said that with error analysis, learners could know the difficulty that they face in grammar, and teachers could know if they are successful in teaching the material in question. The focus of the researchers of the current study was on word order, verb tense, subject-verb agreement, and reference-pronoun agreement.

\section{b. Punctuation Errors}

Arama (2009-2010) stated that punctuation marks have the same duties of facial expressions and body language; they help readers understand what the writer exactly means. For this reason, errors of punctuation may cause misconception, so students have highly been trained to use them correctly. The researchers of the current study focused on the basic punctuation marks as those of the sentence ends such as the full stop, question and exclamation marks in addition to the usage of the semi-colon, and commas.

\section{c. Spelling Errors}

According to Kusuran (2016) spelling errors were divided into two main categories which were typographic errors and cognitive errors. Typographic errors include adding, omitting, subsitituting, or transferring letters while cognitive errors include those letters have phonetic similarities, such as "akademic" and "academic". Anyhow, since spelling errors often change the meaning of the sentence, and lead to misconception, the researchers of the current research considered all the spelling errors as cognitive, and they divided the erroneous words into frequently and less frequently used words.

\section{d. Coherence Errors}

Ruegg and Sugiyama (2013) referred to coherence as the content organization. They further laid more importance on it than on the mechanics of writing. The researchers of the current study confirm the importance of them together for their effect on attracting the reader's attention and interest. They trained the students to pay attention to organize their writing staring with an introductory sentence supported by explanatory sentences and ending with a concluding sentence.

As for arrangement errors, the researchers of the current study focused on the correct usage of capital letters, correct handwritten letters, and spatial arrangement because the individuals of the target population are prepared to be teachers of English language. Under "arrangement errors", there are the following sub-criteria:

\section{a. Capitalization}

Although McCaskill (1990) displayed different opinions and rules concerning capitalization, the researchers of the current study focused only on some of the essential rules. These rules were to capitalize the first letter of each word at the beginning of a sentence, the first letter of the proper nouns, the first letter of the names of months and days, as well as to capitalize the pronoun "I".

\section{b. Handwriting}


McFarland (2015) referred to the importance of handwriting to brainpower, memory, motor skills, and reading, and confirmed its importance in the early stages of teaching children. In their research, Trafford and Nelson (2003) demonstrated the importance of handwriting to the fluency in reading. Since the illegible writing is sometimes difficult to decipher, and the target students were future teachers, their writing was preferred to be legible and show the correct drawing of letters.

\section{c. Formatting}

Based on the researchers' experience as teachers, arranging the written paragraph according to the known spaces of indentation and reasonable spaces between words is one of the important aspects to attract the readers' attention and interest, and to avoid their frustration.

All such types of errors are thought to have their direct effect on the readers' interest, and indirect effect their comprehension. Carelessness to avoid such errors make readers feel bored and have a bad impression on the writer. They further prevent readers from continuing their reading. Careless writers fail to involve and convince their audience in their writings.

\section{LITERATURE REVIEW}

As far as the writing skill is concerned, a considerable amount of literature has been conducted using error analysis where most of it has been descriptive by nature. For instance, Salebi (2004) conducted an error analysis study of midterm test answer sheets of 32 Saudi female students at the $4^{\text {th }}$ college level. According to the study, the students committed 207 errors. Providing the students with feedback, Salebi asked them to comment on their errors showing the causes behind committing them. Accordingly, Salebi classified the errors into two kinds: developmental (students' efficiency), and interferential (Arabic and English) errors. The most of the blame was on the teachers and their methods of teaching.

Mungungu (2010) conducted a quantitative study to identify the errors committed in writing by three Namibian groups: Oshiwambo, Afrikaans and Silozi. He, then, compared the types and frequency of their errors. The sample consisted of 360 essays written by 180 participants from different secondary schools in different regions; each group consisted of 60 ones. The focus of the study was on the errors committed by the participants in tenses, prepositions, articles, and spelling. The study has further shown that the highest number of errors was committed by the Oshiwambo group, and then the Silozi group; the lowest number of errors was committed by the Afrikaans.

Sarfraz (2011) examined the errors of 50 English essays written by 50 undergraduate Pakistani students. The focus of the study was on identifying, describing, and evaluating errors committed by the 50 participants. Sarfraz thought that 61 out of 76 errors were resulted from the inter-language process, which implies bad habits of learning strategies. Besides, other 15 errors were due to the mother tongue interference. Sarfraz also ascribed the errors to the lack of practice, feedback, motivation and carelessness of the part of the students.

Jayasundara and Premarathna (2011) examined the errors committed in writing and speaking by the $1^{\text {st }}$ year level students of Uva Wellassa University, Sri Lanka. Concerning writing, they pinpointed the errors committed by 55 students in their essays written on "The life in my university". Results have shown that more than $80 \%$ of the total errors were related to grammar, spelling, and syntactic categories. Jayasundara and Premarathna further ascribed the reason of the students' weakness to the teachers and the adopted curriculum.

Sawalmeh (2013) investigated the errors of 32 essays written by 32 Saudi learners of English at the university preparatory year program. The study uncovered that the essays contain ten common errors: (1) verb tense, (2) word order, (3) singular/ plural form, (4) subject-verb agreement, (5) double negatives, (6) spelling, (7) capitalization, (8) article, (9) sentence fragment, and (10) prepositions. Sawalmeh also attributed the committed errors to Arabic -the mother tongue- English interference.

The focus of Faisal's study (2013) was only on the syntactic errors committed by 50 participants from the $4^{\text {th }}$ year university students of Educational and Psychological Sciences Department, College of Education for Human Sciences /University of Babylon. She classified the errors into syntactic categories: omission, substitution, addition, and permutation (word order). She also attributed the errors committed to Arabic -the mother tongue- English interference, the rarity of feedback and focus on sentence components in their earlier years of learning, and to the rarity of practicing writing in their current learning process.

Al-Khasawneh (2014) identified the types of errors committed in English paragraph writing by 26 Jordanian students of different majors at Ajloun National University. After categorizing the errors into the wrong use of articles, prepositions, subject-verb agreement, word order, tense, plurality, spelling, capitalization, sentence structure, demonstrative, and irregular verbs, the highest frequency of errors was in the use of articles. Al-Khasawneh thought that such errors were committed due to the insufficient exposure to the target language, lack of practice, and to interference.

As it is shown, the majority of the studies ascribed the reasons of committing errors in writing to the interference between the native and non-native languages, the lack of practice and feedback from the early years of learning in addition to the lack of the students' motivation and carefulness in following their teachers' instructions and to the use of the internet. No doubt, the role of teachers, curriculum, and the exposure to the foreign language is also important for improving the students' writing. To the researchers of the present work, Salebi's way of letting the students comment on their errors is a good way to help them recognize the errors and overcome them. Further, these studies consistently 
showed that students suffer from several major drawbacks in writing. These drawbacks have a serious effect on the quality of their writing. Sometimes, students think that they are doing well; they cannot perceive that their writing has changed the real meaning of the information because of committing many errors, and as a result, they gain low marks.

As far as the current study is concerned, the researchers noticed that in spite of adopting different strategies of teaching and learning through the long study years, starting from the elementary school, passing through the intermediate, and preparatory schools, and ending with the university level, university teachers are mostly shocked by the frequency of the simple errors committed by the students. Such errors are considered the basics of writing; they are not expected to be committed by the undergraduate students of the English Department. Accordingly, the researchers of the present research seek to examine the type and frequency of errors committed by second year students when writing a paragraph.

The study will be limited to participants from the Department of English, College of Education for Women/ University of Baghdad. The size of the sample consisted of 87-second level female students. The students who accepted to participate in the study were homogeneous in their educational background and age; they were all between 20-21 years. Although the students have studied the basics of English writing for about ten years, the researchers focused on the points mentioned in the rubric that reflect the four month teaching conducting on the part of one of the researchers.

The two exams represented follow-up exercises. Such a step helped students to pinpoint their errors, focus on them, know about the governed rules and the non-governed ones, present some possible solutions and/or strategies that help to avoid such errors, and finally set a foundation for the development of more applicable curriculum and methods of teaching. The focus on the perfection of writing is multiplied when it is taught to students who are going to be teachers of language in general, and English as a foreign language, in particular.

\section{Methodology of THE Study}

To meet the objective of the study, which reads, examining the type and frequency of errors committed by the subject of the study when doing paragraph writing, the researchers passed through the following steps:

- Designing a rubric that covers both the recognition and arrangement errors, as shown in Appendix (I);

- Teaching the subject paragraph writing. That is; the participants were required to be trained on writing paragraphs according to the following qualities:

a. logical sequence of ideas starting with an introductory sentence, then the supporting, and concluding ones; b. good grammar, spelling, and punctuation; c. well-arranged concerning capitalization, handwriting, and formatting;

- Examining the subject twice and asking them to use the designed rubric to check their errors whenever they write a paragraph; and

- Conducting the third test. The question that was given to the subject was "Write a paragraph to describe 'Your best friend' taking into consideration the qualities of a good paragraph within a period of half an hour";

- Analyzing the writings using the designed rubric. This step involved the following sub-steps:

- Identifying the participants' errors;

- Categorizing them into the seven categories identified in the designed rubrics;

- Calculating the number of the participants as per the errors being tested; and

- Deriving the conclusions.

As it is shown, the present study is qualitative and quantitative by nature. It aims at knowing both the type and frequency of the errors committed to be able to help the students to know how to avoid those errors, and show the teachers how they could help their students to conduct a self-assessment.

\section{ANALYsis, Results AND Discussion}

Examining the participants' writing once they have taken the test, the researchers categorized the types of errors and fixed the number of the students who committed those errors as shown in Table (1) below:

TABLE (1):

TYPES OF ERRORS AND THE NUMBER OF STUDENTS FOR EACH

\begin{tabular}{|l|l|l|l|l|}
\hline Seq. & Category & No. of Students \\
\cline { 3 - 5 } & & Poor & Satisfactory & Distinguished \\
\hline 1 & Grammar & 70 & 15 & 2 \\
\hline 2 & Capitalization & 66 & 9 & 12 \\
\hline 3 & Spelling & 54 & 23 & 10 \\
\hline 4 & Punctuation & 37 & 34 & 16 \\
\hline 5 & Formatting & 21 & 47 & 19 \\
\hline 6 & Handwriting & 14 & 55 & 18 \\
\hline 7 & Coherence & 8 & 64 & 15 \\
\hline
\end{tabular}

Based on Table (1), results have shown the following:

- Majorly the types of errors committed by the participants revolved around the following categories: grammar, capitalization, and spelling; 
- The highest number of students as per to the three majorly mistaken categories: grammar (70), capitalization (66), and spelling (54);

- The highest number of the distinguished students was only (19) as far as the "Formatting" was concerned;

- It was further surprising to notice that a considerable number of the participants committed unexpected errors; a matter that reflected their lack of concentration; cases in point are errors in capitalizations, formatting, and handwriting;

- Contrary to expectations, the number of the participants who obtained the "Distinguished" level in formatting and handwriting was very limited, and those who obtained the "Poor" level in coherence was very limited while the number of the participants who obtained the "Satisfactory" level in coherence was the highest among the other categories of the same level;

- Although the researchers taught and trained the participants about the rules of coherent paragraphs, the importance of starting a paragraph with a well-organized topic sentence, followed by supporting sentences, and a closing sentence, it was found that participants sometimes used long and complex sentences with unsuitable vocabulary; a matter that made it difficult for them to connect ideas well together;

- It was noticed that most of the participants had memorized the example given to them during the previously conducted follow-up tests, as a result they showed no creativity;

- A considerable number of the participants used punctuation randomly although they were required to use only the basic ones which had to be familiar to them;

- Unfortunately, more than half of the participants were "Poor" in spelling; this might be attributed to teachers' carelessness at the early years of teaching;

- Though teaching capitalization has been started since the early years of teaching English, yet only (12) participants out of (87) showed a complete awareness of using it;

- The participants were told about the importance of formatting concerning paragraph length, indention, and margins to show concern for keeping readers interested. They were taught that the length of a good paragraph ranges between five lines and half of a page in order to avoid committing more errors and boring more readers. Though they were all trained to describe briefly, indent the beginning of each paragraph, and leave margins from the two sides, it was found that only 19 participants were distinguished as shown in table (1);

- Despite the fact that the participants were encouraged to improve their handwritings, and pay attention to draw letters correctly, leave reasonable spaces between letters and words, it was revealed that only 18 participants were distinguished as shown in table (1).

\section{CONCLUSIONS}

It is to be concluded that:

- The participants showed weakness in the seven tested categories: grammar, spelling, punctuation, coherence, capitalization, formatting, and coherence;

- It was clear from the results that not all teachers follow up with their students to get used to correcting themselves when they practice writing;

- The researchers ascribed the reasons behind committing such errors to external and internal factors. The external factors are represented by having busy teachers, who are assigned the duty of teaching more than one stage. Such a reason leaves no effort or space for the teachers to train their students to overcome their weak points. Besides, teachers have no time to adopt a specific rubric and ask their students to use it when writing. In addition, to follow up with the students involve having a limited number of students; a matter that is not applicable to the subject's classrooms. The internal factors are represented by the participants' internal desire and motivation, which are greatly affected and enhanced by the external factors;

- Generally, the findings are disappointing because of the considerable number of the participants who obtained the "Poor" level in the different categories, which were supposed to be learnt from the early years of their study;

- The disappointing results represent clear indications for researchers to revise their methods of teaching and decide where they have to stop and focus according to the mentioned results.

\section{RECOMMENDATIONS}

The researchers suggest some possible solutions to improve the students' level and avoid these errors:

1. It is important that teachers agree to adopt a specific rubric to help in examining their students' errors;

2. Dedicating scores to encourage students to do extracurricular on writing;

3. Students must not move from simple sentence constructions to compound and complex sentences unless they govern the first;

4. Teachers should attract students' attention to both grammar and punctuations;

5. Spelling cannot be improved without the repetition of writing;

6. To enhance the students' writing, curriculum designers must take into account the results of the above mentioned table, and add more various exercises;

7. Activating the role of establishing writing centers in all academic institutions; 
8. Before involving in the job of teaching, graduates have to complete additional remedial and enhancement programs, and

9. Establishing committees to follow up the new graduates in their jobs as teachers for a year at least.

APPENDIX

\begin{tabular}{|c|c|c|c|c|c|}
\hline \multicolumn{6}{|c|}{ Error Analysis of a Paragraph Writing } \\
\hline \multicolumn{3}{|l|}{ Criteria } & \multirow{2}{*}{$\begin{array}{l}\text { Poor } \\
\text { More than } 3 \text { errors }\end{array}$} & \multirow{2}{*}{$\begin{array}{l}\text { Satisfactory } \\
1-3 \text { errors }\end{array}$} & \multirow{2}{*}{$\begin{array}{l}\text { Distinguished } \\
\text { No error }\end{array}$} \\
\hline & Grammar & $\begin{array}{l}\text { Word order } \\
\text { Suitable tense } \\
\text { S-V agreement } \\
\text { P-Ref } \\
\text { agreement }\end{array}$ & & & \\
\hline & Punctuation & $\begin{array}{l}\text { Sent. ending } \\
\text { Comma } \\
\text { Semicolon }\end{array}$ & More than 2 errors & $1-2$ errors & None is missing \\
\hline & Spelling & $\begin{array}{l}\text { Frequently used } \\
\text { words } \\
\text { Less frequently } \\
\text { used words } \\
\end{array}$ & $\begin{array}{l}\text { Either more than } 1 \\
\text { frequently used word, or } \\
\text { more than } 3 \text { less frequently } \\
\text { used ones }\end{array}$ & $\begin{array}{l}\text { Either only } 1 \text { frequently used } \\
\text { word, or } 2-3 \text { less frequently } \\
\text { used ones }\end{array}$ & $\begin{array}{l}\text { Only } 1 \text { less frequently word } \\
\text { is accepted }\end{array}$ \\
\hline & Coherence & $\begin{array}{l}\text { Introductory } \\
\text { Supporting } \\
\text { Conclusion }\end{array}$ & $\begin{array}{l}\text { None is clear; hard to } \\
\text { understand }\end{array}$ & $\begin{array}{l}\text { Some are applied; easy to } \\
\text { understand, but sents. aren't } \\
\text { perfectly connected to each } \\
\text { other }\end{array}$ & $\begin{array}{l}\text { All perfectly applied; } \\
\text { understandable \& sents. are } \\
\text { perfectly connected to each } \\
\text { other }\end{array}$ \\
\hline \multirow{3}{*}{$\frac{\text { Recognition }}{\text { Arrangement }}$} & Capitalization & $\begin{array}{l}\text { Sent. beginning } \\
\text { Proper nouns, } \\
\text { months \& days } \\
\text { the pronoun "I" }\end{array}$ & More than 2 errors & $1-2$ errors & No error \\
\hline & Handwriting & $\begin{array}{l}\text { Correct image } \\
\text { Spaces between } \\
\text { letters \& words }\end{array}$ & $\begin{array}{l}\text { Incorrect images of more } \\
\text { than } 3 \text { letters, and/or } \\
\text { incorrect spacing }\end{array}$ & $\begin{array}{l}\text { Incorrect images of only 1-3 } \\
\text { letters and/or incorrect spacing }\end{array}$ & No error \\
\hline & Formatting & $\begin{array}{l}\text { Length } \\
\text { Leaving } \\
\text { margins } \\
\text { Indent }\end{array}$ & None is applied & Two items are missing & Only 1 item is missing \\
\hline
\end{tabular}

\section{REFERENCES}

[1] AL-Khasawneh, Fadi Maher. (2014). Error Analysis of Written English Paragraphs by Jordanian Undergraduate Students : A Case Study, International Journal of English Language, Literature and Humanities, Vol. II, Issue VIII, Retrieved on 10 March, 2017 from: https://www.researchgate.net/publication/281864190_Error_Analysis_of_Written_English_Paragraphs_by_Jordanian_Undergr aduate_Students_A_Case_Study.

[2] Arama, Miss Asma. (2009-2010). The Comma and the Period: From Rote Learning to Efficient Classroom Practice. The Case of Second Year Students, University of Constantine, M.A. diss., University of Constantine, Retrieved on 30 November, 2017from: https://bu.umc.edu.dz/theses/anglais/ARA1110.pdf.

[3] Baghzou, Sabrina. (2011). The Effects of Content Feedback on Students' Writing, Ankara Üniversitesi Dil ve Tarih-Coğrafya Fakültesi Dergisi, 51, 2. Retrieved on 4 June, 2017 from: http://dergiler.ankara.edu.tr/dergiler/26/1661/17733.pdf.

[4] Corder, S. P. (1967). The Significance of Learners' Errors. Internationat Review of Applied Linguistics in Language Teaching, IRAL, Vol. 4. Retrieved on 30 June, 2017 from: http://files.eric.ed.gov/fulltext/ED019903.pdf.

[5] Darus, Saadiyah \& Subramaniam, Kaladevi. (2009). Error Analysis of the written English Essays of Secondary School Students in Malaysia: A case study, European Journal of Social Sciences - Volume 8, Number 3, 483-495, Retrieved on 28 June, 2017 from: http://www.researchgate.net/publication/235772401_Error_analysis_of_thewritten_english_essays_of_secondary_school_stude nts_in_Malaysia_A_case_study.

[6] Deane, Paul et. al. (2008). Cognitive Models of Writing: Writing Proficiency as a Complex Integrated Skill, Princeton, NJ. Retrieved on 26 May, 2017 from: https://www.ets.org/Media/Research/pdf/RR-08-55.pdf.

[7] Faisal, Wafaa Mokhlos. (2013). Syntactic Errors Made by Students of Department of Educational and Psychological Sciences, Journal of Babylon University, Vol. 21, Issue 2, Retrieved on 10 July, 2017 from: http://www.iasj.net/iasj?func=fulltext\&aId=77375.

[8] Graham, Steve \& Herbert, Michael. (2011). Writing to Read: A Meta Analysis of the Impact of Writing and Writing Instruction on Reading, Harvard Educational Review, Vol. 81, No. 4, Retrieved on 9 July, 2017 from: http://www.studentachievement.org/wp-content/uploads/Writing-to-Read.pdf.

[9] Hasyim, Sunardi. (2002). Error Analysis in the Teaching of English, Kata, Vol. 4, No. 1, Petra Christian University, Retrieved on 6 August, 2015 from: kata.petra.ac.id/index.php/ing/article/download/15485/15477.

[10] Homstad, Torild and Thorson, Helga. (1994). Writing Theory and Practice in the Second Language Classroom: A Selected Annotated Bibliography, Technical Report Series, No. 8, Lillian Bridwell-Bowles, Series ed. Retrieved on 25 May, 2017 from: http://writing.umn.edu/isw/assets/pdf/publications/Homstad_Thorson94.pdf. 
[11] Homstad, Torild and Thorson, Helga. (1996). Using Writing-to-Learn Activities in the Foreign Language Classroom, Technical Report Series, No. 14, Lillian Bridwell- Bowles, Series ed. Retrieved on 11July, 2017 from: http://writing.umn.edu/isw/assets/pdf/publications/Homstad_Thorson96.pdf.

[12] Jayasundara J.M.P.V.K. and Premarathna C.D.H.M. (2011). A Linguistics Analysis on Errors Committed in English by Undergraduates, International Journal of Scientific and Research Publications, Vol. 1, No. 1, Retrieved on 11 July, 2017 from: http://www.ijsrp.org/research_paper_dec2011/ijsrp-dec-2011-05.pdf.

[13] Kusuran, Amir. (2016). L2 English spelling error analysis: An investigation of English spelling errors made by Swedish senior high school students, Faculty of Humanities and Social Sciences, diva portal.org. Retrieved on 25 May, 2018 from: http://www.diva-portal.org/smash/get/diva2:1078118/FULLTEXT01.pdf.

[14] McCskill, Mary K. (1990). Grammar, Punctuation, and Capitalization: A Handbook for Technical Writers and Editors, Langley Research Center, Hampton, Virginia, Retrieved on 20 May, 2018 from: https://ntrs.nasa.gov/archive/nasa/casi.ntrs.nasa.gov/19900017394.pdf.

[15] McFarland, Erin. (2015). The Importance of Handwriting: How Montessori Didactic Materials Support Handwriting, a Master's Paper Submitted in Partial Fulfillment of the Requirements for the Degree of Master of Science in EducationMontessori, The University of Wisconsin - RiverFalls, Retrieved on 1 December, 2017 from: https://minds. wisconsin.edu/bitstream/handle/1793/72252/ErinMcFarland.pdf.

[16] Mungungu, Saara Sirkka. (2010). Error Analysis: Investigating the Writing of ESL Namibian Learners, Master of Arts - with specialization in TESOL, University of South Africa, Retrieved on 11 March, 2017 from: http://citeseerx.ist.psu.edu/viewdoc/download?doi=10.1.1.833.5369\&rep=rep1\&type=pdf.

[17] Nzama, Muzi V. (2010). Error Analysis: A Study of Errors Committed by Isizulu Speaking Learners of English in Selected Schools, M.A. diss., the Department of General Linguistics at the University of Zululand, Retrieved on 30 April, 2016 from: http://uzspace.uzulu.ac.za/bitstream/handle/10530/615/error\%20analysis.pdf?sequence=1.

[18] Ruegg, Rachael and Sugiyama, Yuko. (2013). Organization of Ideas in Writing: What are Raters Sensitive to? Language Testing in Asia, Retrieved on 30 November 2017 from: https://link.springer.com/content/pdf/10.1186\%2F2229-0443-3-8.pdf.

[19] Salebi, Mohamed Y. (2004). Saudi College Students' Perception of Their Errors in Written English, Scientific Journal of King Faisal University (Humanities and Management Sciences) Vol. 5, No.2, Retrieved on 1 June, 2017 from: https://apps.kfu.edu.sa/sjournal/eng/pdffiles/a526.pdf.

[20] Sarfraz, Summaira. (2011). Error Analysis of the Written English Essays of Pakistani Undergraduate Students: A Case Study,

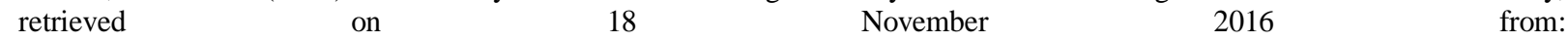
http://citeseerx.ist.psu.edu/viewdoc/download;jsessionid=33C1C72EC259F65EFDCA214B32CC4E07?doi=10.1.1.676.1819\&r ep=rep1\&type $=$ pdf.

[21] Sawalmeh, Murad Hassan Mohammad. (2013). Error Analysis of Written English Essays: The Case of Students of the Preparatory Year Program in Saudi Arabia, English for Specific Purposes World, ISSN 1682-3257, Issue 40, vol. 14 Retrieved on 2 June, 2017 from: http://www.esp-world.info/Articles_40/Sawalmeh.pdf.

[22] Trafford, Charles H. and Nelson, Rand H. (2003). Handwriting: A Complete Guide to Instruction-Teaching Physical Patterns for Reading and Writing Fluency, Peterson Directed Handwriting, Greensburg, Pennsylvania. Retrieved on 17 March, 2017 from: https://www.peterson- handwriting.com/Publications/PDF_versions/ReviewSections123.pdf.

[23] Weireesh, S. (1991). How to Analyze Interlanguage, Journal of Psychology and Education, 9 in Darus, Saadiyah \& Subramaniam, Kaladevi (2009). European Journal of Social Sciences, Volume 8, No.3, Retrieved on 28 June, 2017 from: http://www.researchgate.net/publication/235772401_Error_analysis_of_thewritten_english_essays_of_secondary_school_stude nts_in_Malaysia_A_case_study.

Iman M. Muwafaq Al-Ghabra was born in Baghdad, Iraq on the second of February, 1956. She received the BA in English Language from the College of Arts, University of Al-Mustansiryah, Baghdad, Iraq in 1978, and the MA in Linguistics from the College of Education for Women, University of Baghdad, Baghdad, Iraq in 1988. She is now a lecturer at the Department of English, College of Education for Women.

She taught English in the different departments of the University of Technology, Institute of Iraqi Railways, University of Baghdad, University of Taiz, Yemen. The latest articles are: "Helping EFL Students Improve their Writing, International Journal of Humanities and Social Science, Volume 4, Issue 2, 2014", "Handwriting: A matter of affairs, English Language Teaching, Volume 8, Issue 10, 2015"; she is a coauthor with Asst. Prof. Maysaa R. Abdul Majeed of "Technology Usage in English Language Teaching and Learning: Reality and Dream, Journal of the College of Education for Women, Volume 27, Issue 6, 2016".

Ms Muwafaq Al-Ghabra is a member of TESOL (Teachers of English to Speakers of Other Languages), and ITA (Iraqi Translators Association-Baghdad).

Afrah S. Najim was born in Baghdad, Iraq on the eighth of February, 1986. She received the BA in English Language from the College of Education for Women, University of Baghdad, Baghdad, Iraq in 2016; she was one of the top students. She is now a teacher in a primary school; she teaches English as a Foreign Language.

She has completed two courses for teaching and assessment in the ELT teach professional development program for English language teachers in 2017. Seeking information and research, she has not cut contact with the university professors trying to prepare for higher studies. 